Special Issue on Migration and Globalization, Canadian Studies in Population

Vol. 29(1), 2002, pp 71-99

\title{
Skilled Immigrant Labour: Country of Origin and the Occupational Locations of Male Engineers
}

\author{
Monica Boyd \\ University of Toronto \\ Toronto, Ontario \\ Derrick Thomas \\ Statistics Canada \\ Ottawa, Ontario
}

\begin{abstract}
Do high skill immigrant workers find employment corresponding to their training? Using unpublished data from the 1996 census, we examine the occupational locations of men age 30-54 who have a university degree with a major in engineering. We focus on three groups: Canadian born, foreign born who immigrated before age 19 and the foreign-born arriving after age 27, arguing that the first two are most likely to be educated in Canada whereas the last group is not. We find birth place differences in the percentages who are working in managerial, engineering, technical and all other occupations, with differences being most pronounced for those immigrating after age 27. Multinomial logit analysis confirms that these differences cannot be attributed to differences in measured human capital stock. Accreditation requirements are one likely explanation, particularly for those who have received training outside Canada.
\end{abstract}

Key Words: engineers, accreditation, foreign-born, occupation 


\section{Résumé}

Les immigrants hautement qualifiés trouvent-ils de l'emploi correspondant $r$ leur formation? R l'aide de données non publiées du Recensement de 1996, nous examinons la situation professionnelle des hommes de 30-54 ans qui ont un grade universitaire avec majeure en génie. Nous nous intéressons $r$ trois groupes: les personnes nées au Canada, les personnes nées à l'étranger qui ont immigré avant 19 ans et les personnes nées à l'étranger arrivées après 27 ans, partant du principe que les deux premiers groupes sont très susceptibles d'avoir fait leurs études au Canada, au contraire du dernier groupe. Nous observons des différences de lieu de naissance au niveau des pourcentages de ceux qui occupent des postes de direction, en génie, en technique et dans l'qui ont immigré après l'âge de 27 ans. L'analyse multinomiale des logits confirme que ces différences ne peuvent être attribuées à des différences du stock de capital humain mesuré. Les exigences d'accréditation sont une explication probable, particulièrement pour ceux qui ont acquis leur formation à l'extérieur du Canada.

Key Words: engineers, accreditation, foreign-born, occupation

\section{Introduction}

Economic globalization, based on worldwide networks of communication, transportation, economic transactions, and the market and production strategies of companies, has produced the mantra of the early 21st century - Aeconomic competitiveness in a knowledge based society.@ For countries of immigrant settlement, this mantra means that the recruitment of high-skilledlabor is forefront in the immigration policy arena .

Canadian efforts to attract high skilled immigrants are not new. In the second half of the twentieth century, considerable attention was paid to flows of human capital and to its utilization in Canada $=$ s post-industrial society Well known early studies were those by the Department of Labour (Canada. Department of Labour, 1961); Parai (1965); Atkinson, Barnes and Richardson (1970). In this early research, three core themes existed: 1) the contribution of immigrant professionals to $\mathrm{Canada}=\mathrm{s}$ stock of skilled labor; 2) ethnic group or country of origin differentials in the contribution of immigrant professionals; and 3) cross-border flows between the United States and Canada. By the start of the new millennium, the third theme became part of a debate not about immigration policy but about fiscal policy, especially focused on personal taxation laws (Boyd, 2001; also see the two following websites: www.isuma.net/vol01n01; and "Publicly Available Sites on Canada's Brain-Drain" under "Related Links and Reports," strategis.ic.gc.ca/sc_ecnmy/engdoc/homepage.html). 
Despite recent attention to the "brain drain," the second theme remains central in any discussion on foreign trained high skilled labour. Indeed, it becomes even more important given shifts in immigrant origins that followed regulatory changes in 1962 and 1967 and the Immigration Act, 1976 (effective 1978). Alterations in admissibility criteria from those of national origins to those based on principles of family reunification, humanitarian considerations and economic contributions dramatically changed the country-of-origin composition of the foreign born population in Canada. According to the 1951 census, 97 percent of the foreign born population was born in the U.S., U.K. or Europe. By the 1996 census, only a slight majority of foreign-born permanent residents were from these areas, with 48 percent born in Asia or in other regions such as Africa or South America (Boyd and Vickers, 2000, Chart 6).

In earlier investigations into the ethnic origins of high skilled foreign workers, two demographic questions dominated: a) what was the ethnic origin composition of high skilled workers; and b) specific to each ethnic group, what percentages of the total stock or flows consisted of the high skilled? Today, a third question exists: do high skilled immigrants from areas other than the United States and Western Europe (including the U. K.) find employment in areas of their training to the same extent as the Canadian born or those from Anglo-European countries (Boyd, 1994). This question derives from sociological and economic considerations. From a social inequality perspective, differences by country of origin are yet another indication of immigrant stratification, reflecting possible employer discrimination, difficulties in obtaining educational recognition and accreditation barriers (Boyd and Thomas, 2001). From an economic perspective, the failure of workers to find jobs commensurate with their training implies labour market inefficiencies and potential under-utilization of skills.

To date, research design requirements and related data needs have hampered production of a comprehensive picture of birth place differences in the occupational match or mismatch of high skill immigrant workers. Because high skilled workers are a select group, characterized by educational specialization and training for work in certain jobs, considerable detail about specialization and work is required to determine if skilled foreign born workers are employed in the jobs for which they are trained. Case studies of specific professions help fill the gap, but often such studies are limited to workers of a particular origin and in specific organizations and cities (see: Basran and Zong,1998; Calliste, 2000; Das Gupta, 1996, Chapter 6). Publicly available micro-data sets such as the 1996 Public Use (Census) Micro-Data Files or the Survey of Labour and Income Dynamics also offer limited insights. These data sets either have small numbers for select birth place/visible minority groups (SLID) and/or contain aggregated data for crucial variables such as postsecondary majors and occupations, blunting the analyses that can be undertaken.

In this paper, we address the question of whether or not high skilled immigrants from areas other than the United States and Western Europe (including the U. K.) find employment in areas of their training to the same extent as other immigrants or the Canadian born. To answer this question we use data from the 1996 2B census data housed at Statistics Canada. We focus on one specific profession, 
engineering, and analyze the country of origin variations in the occupations held by men who have at least a bachelor's degree with engineering declared as a major field of study. We find a pattern of differential labor market insertion that strongly parallels the vertical mosaic, so well documented by John Porter in the 1960s. Men who are born in the United Kingdom, and in the United States, European countries other than Eastern Europe, and in Oceania (primarily Australia) have occupational profiles similar to Canadian born men with engineering training. At the other end of the spectrum, men who are from the Philippines are the least likely to be employed in engineering occupations. Multinomial logit analyses confirms that these differencescannot be attributed to differencesin measured human capital stock. One likely explanation is that certification requirements impact differentially on birth place groups, particularly when degrees are received from non-Canadian institutions..

\section{Engineering and Country of Origin: A First Look}

Engineering is chosen for study because many North American firms are now exporting engineering services as part of the new mantra of "economic competitiveness in a global economy". Canada's consulting engineering sector produces total revenues of close of 10 billion, and it ranks fourth largest in the world in terms of international billings (Industry Canada, 2001). Engineering also is a professional occupation that relies on a global labor supply. United States use of foreign born engineers, many of whom are $\mathrm{H}-1 \mathrm{~B}$ visa holders, is well documented (Alarcon, 1999, 2000; Fernandez, 1998; Lim, Waldinger, and Bozorgmehr 1998). In Canada, the foreign-born are close to half of those in the 1995-1996 experienced labor force, who are age 15 and older, and who list engineering as a post-secondary major field of study. Most (97 percent) are permanent residents (unpublished tabulations from the 1996 2B census database).

Flow data for Canada confirm that workers in engineering continue to have an important presence in contemporary permanent resident admissions. At first glance, however, the impact appears marginal. Of men who are age 25-64 at entry and were admitted to Canada as permanent residents between 1980-1996, 8 percent declared engineering or engineering related occupations (Table 1). This percentage does not take into account that engineering training usually is obtained through university education, and nearly two-thirds of these men admitted as permanent residents have university degrees (Table 1, column 3). Among those men entering Canada who have university degrees or higher, nearly one in five (19 percent) declare their occupations to be in either engineering management, engineering, or technical work in engineering (Table 1, column 5).

Flow data also show that immigrants who declare their occupations to be in engineering come from diverse origins, associated with the more general post-1960s shift in source countries away from the U.S., the U.K. and Western Europe. For men age 25-64 who indicated engineering occupations during 1980-1995, and who had university degrees, less than 15 percent were born in the United States, the UK or elsewhere in North or Western Europe. Slightly more than one-quarter of all 


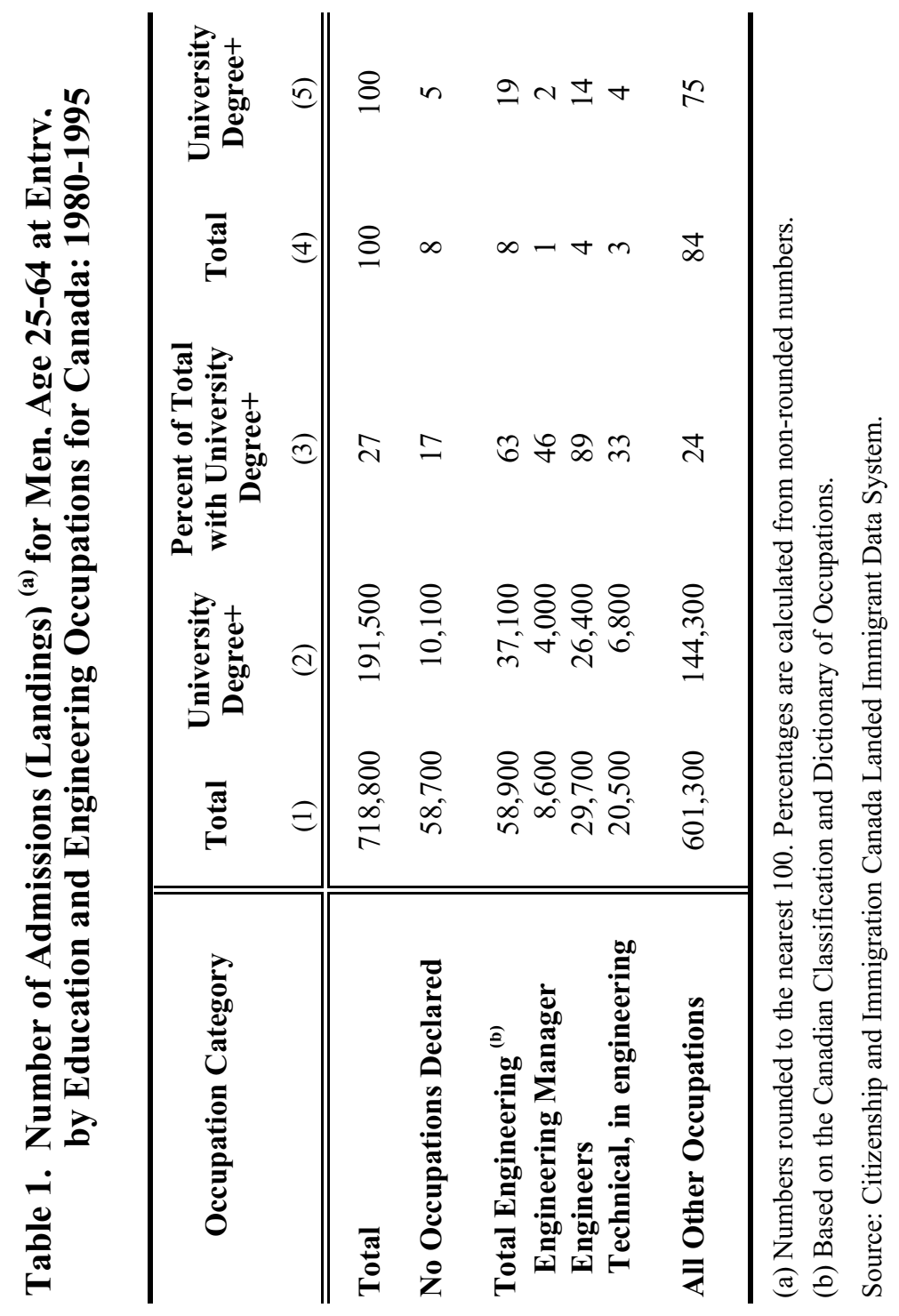




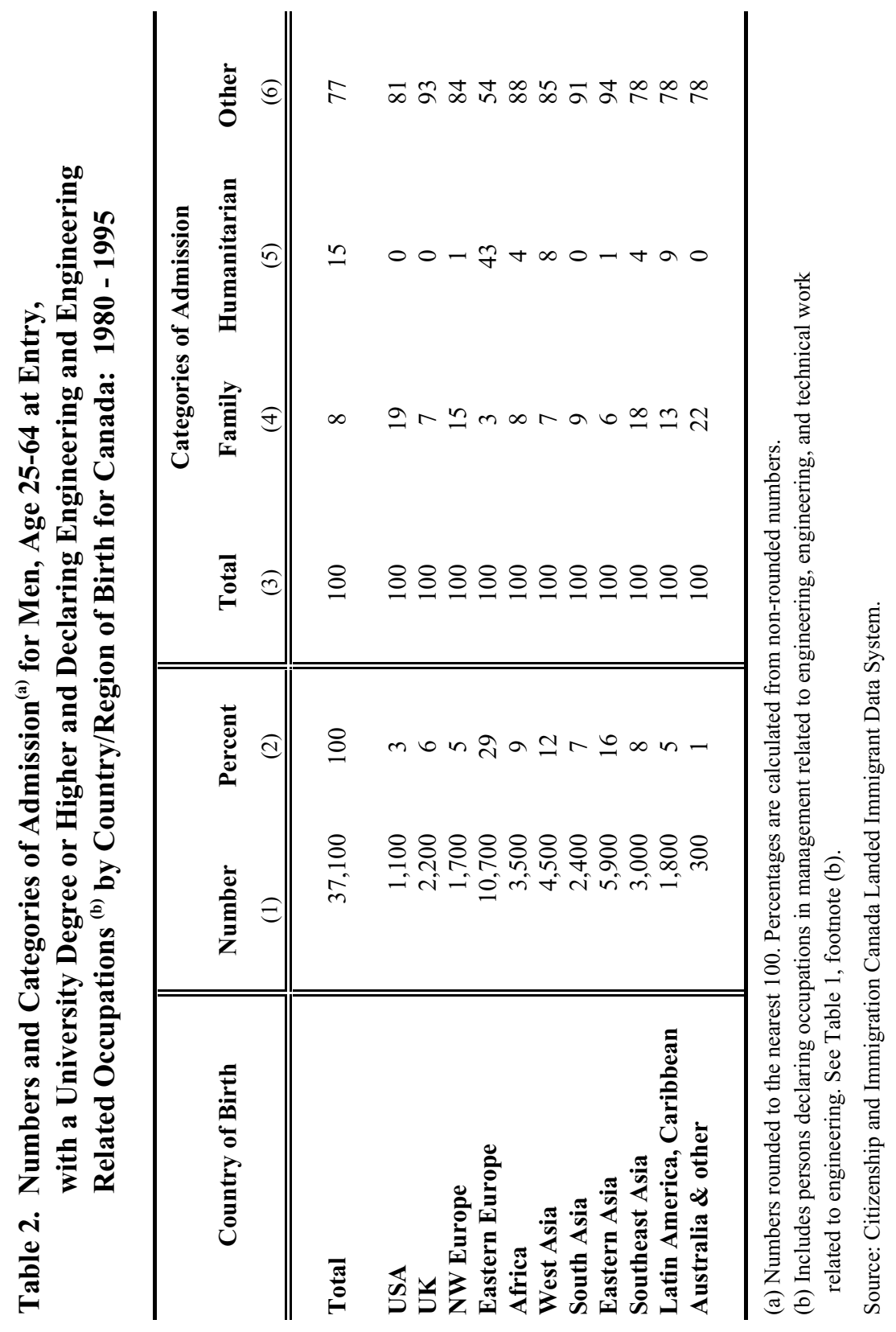


Skilled Immigrant Labour: Country of Origin and the Occupational Locations of Male Engineers

immigrant men are born in countries of either Western Asian or Eastern Asia. Altogether, immigrants from areas other than Europe (including the U.K., NW and Eastern Europe) account for the majority (57 percent) of immigrants who declare engineering or engineering related occupations. However, a surprising percentage is from Eastern Europe, most probably reflecting the political upheaval associated with the break-up of the U.S.S.R. In general, during 1980-1995, less than onequarter of all men in the specified population who gave engineering or related occupations entered in the family or humanitarian classes. However, for those born in Eastern Europe, four out of ten (43 percent) entered Canada on the basis of humanitarian considerations.

\section{Different Origins and Patterns of Labour Market Integration}

Once Canadian residency is established, immigrants usually enter the labour force. It is at this juncture that the question arises: do immigrants find employment that is consistent with their human capital skills? In a recent study of immigrant engineers using the 1996 census, we examine the match between educational training and subsequent occupational locations for Canadian-born and foreign-born men who have at least 16 years of schooling and a bachelors degree and who declare engineering as their major field of study (Boyd and Thomas, 2001). Compared to men who either are Canadian born or immigrated as children, immigrant men who arrive after age 27 and presumably receive their training elsewhere are: 1) the least likely of the three groups to be in the labor force or employed; 2) when employed, they are less likely to hold either manager, engineering or technical occupations, and most likely to be employed in other occupations; 3 ) differences attenuate for those with advanced degrees and long durations in Canada. Men with engineering training who have been in Canada 15 years or more and/or who have Masters and Ph.D. degrees have employment patterns and occupational profiles that more closely correspond to those of their Canadian-born counterpartsor those arriving as children.

In this initial study we did not examine differences by country of origin. Diverse source countries in immigration flows recasts the generic question asked by Boyd and Thomas (2001) to one that asks if matches between training and occupations among foreign born are more likely for some origin groups with engineering training than others. We anticipate that immigrants who are born in the U.S., the U.K. and other European countries will be more likely than groups born in areas such as Latin America and Asia to work in engineering and related occupations.

One reason for expecting differences by country of origin in the labour market integration of foreign-born engineers is that immigrants always bring into their new surroundings the imprints of their former society. Country differences with respect to languages, educational systems, and economic structures are likely to generate human capital differencesamong those immigrants who receive engineering training. Human capital refers to productivity enhancing knowledge and skills that are embodied in worker, including language skills, the level of education based training, and work experience. 
However, the argument that variations in the stock of human capital explain country of origin differences in labour market outcomes of high skilled workers is incomplete. A second reason for expecting country of origin differences is that discriminatory practices in a receiving society can privilege or reduce the values assigned to human capital variables. Such practices thus affect the hiring process, the occupations held, and the wages paid. For example, education may be devalued, particularly for those immigrants who receive their education outside the host society. Such devaluation may reflect discriminatory barriers which can range from those associated with personal prejudice to those resulting from the imperfect knowledge that an employer has about the content and worth of degrees obtained outside Canada. As well, employers may deliberately devalue foreign credentials in order to lower labor costs and enhance profits (Boyd and Thomas, 2001: 112-113).

Discrimination also can be "systemic," resulting from rules and procedures that are not explicitly designed to produce differential outcomes but do so through their applications.

Accreditation or certification requirements associated with professions are often described as a form of systemic discrimination, in that criteria are created which are universally applied to the Canadian-born and foreign-born alike, but have disproportionate effects in restricting access to a trade or profession among the foreign-born (Basran and Zong, 1998; Bolaria 1992; Mata 1992, 1994, 1999; McDade 1988). It should be noted that certification requirements are not automatically discriminatory. For example, restrictions may be defensible if the content of education or other professional credentials (such as internships or apprenticeships) differ from those in Canada to the point where public health or safety is imperiled. And other certification requirements, such as literacy and speaking ability in the host society language(s) also may be invoked if their absence jeopardizes public safety and health. Nonetheless, concern is growing in Canada over the potential barriers facing immigrants as a result of accreditation requirements. Several provincial task forces have been struck, reports generated, conferences held, and a federal interdepartmental group on the topic established in 1992 (Boyd and Thomas, 2001).

Accreditation requirements are important determinants of the occupations held by persons with engineering training. In Canada, engineering is a regulated profession, meaning that no one can practice the profession of engineering without a license. Licensing is done by 12 provincial and territorial associations/ordre, organized under the umbrella association of the Canadian Council of Professional Engineers (CCPE). Through its Canadian Engineering Accreditation Board, CCPE accredits undergraduate engineering programs in Canada. CCPE also affects the practice of engineering by the foreign born in three important ways. First, it stipulates the conditions that all applicants (Canadian-born and foreign born) must satisfy. Conditions include, but are not limited to: an undergraduate degree in engineering; completion of 3-4 years of engineeringwork experienceincluding a minimum of one year of experience in a Canadian environment, proficiency in English (or French in Quebec and French or English in New Brunswick); status as a Canadian citizen or permanent resident; and the writing and passing of a professional practice examination. 
Skilled Immigrant Labour: Country of Origin and the Occupational Locations of Male Engineers

Second, the CCPE assesses the equivalency of the accreditation systems used outside Canada, and it monitors mutual recognition international agreements affecting accredited programs in the United States, the United Kingdom, Ireland, France, Australia, New Zealand, South Africa and Hong Kong (see website: www.ccpe.ca/ccpe.cfm ).

Third, CCPE operates "The Initial AssessmentProgram," developed in conjunction with Citizenship and Immigration Canada (CIC). This program has a dual function: it helps CIC to determine if applicants for permanent resident status qualify as skilled workers, and it helps prospective immigrants to assess if they have the qualifications required to be licenced as professional engineers, following CCPE requirements. However, CCPE emphasizes that the Initial Assessment Program is not part of the registration process to be licenced. Persons wishing to practice as a professional engineer after arrival in Canada must apply for registration and liscenure to the relevant provincial association and meet those requirements. A question and answer section on the Initial Assessment web-based documentation lists several conditions under which an individual should not proceed with the initial assessment application. These conditions include: absence of a bachelor's degree in engineering from a university; the applicant is a computer programmer, architect, scientist or an agronomist; the applicant has a degree from the Philippines (see website: www.ccpe.ca/ccpe.cfm ). The latter stipulation reflects a licensing requirement of 16 years or more of schooling and the programs in the Philippines (personal conversation, CCPE staff, Ottawa, June 6, 2001).

The preceding discussion indicates a complex set of factors determine who holds an engineering occupation in Canada. Pronounced birth place differences in the experiences of university educated men appear likely for two reasons. First, in keeping with our earlier study, little difference should exist in the labour market experiences of the Canadian born and those who immigrated as children, regardless of country of birth. We based this expectation on the assumption that these two populations have received their professional education from Canadian institutions. Second, among those who received their engineering education outside Canada (defined as those immigrating after age 27), men who are from the U.S.A., the U.K., North and West European countries, and from countries with Canadian international agreements should be more likely to be in occupations commensurate with their training than are those born elsewhere. One reason for this expected pattern might be the greater familiarity of these groups with English and/or French, a fact that would enhance their potential productivity for would be employers and would facilitate re-accreditation where required. A second reason is that the CCPE has mutual agreements with the U.S., the U.K., France, Australia, New Zealand and Hong Kong, thus minimizing the potential barriers associated with accreditation requirements in engineering. 


\section{Data and Other Considerations}

In this paper, data on the engineering profession in Canada are taken from the onein-five sample of the 1996 census of Canada (the 2B questionnaire). This database contains information on birth place, permanent or non-permanent immigrant status, year of arrival, age at immigration, level of education, years of schooling, degrees, fields of major and minor study for those with post-secondary education, and labor force characteristics. The question on major field of study identifies those who underwent training in engineering fields. We devise a four-category classification that collapses 514 occupational titles into four main types of occupations: managers; engineering occupations, technical occupations that are related to engineering activities; and all other occupations ${ }^{1}$. This categorization captures the major outcomes for engineers observed in other studies (Fernadez 1998; Lim, Waldinger \& Bozorgmehr 1998; Tang 1993a, 1993b, 1995, 1997). Although engineering occupations are a logical site of employment for those with engineering training, some individuals will become managers. As well, some individuals trained in engineering will find employment in occupations that are further removed from engineering per se but which are of a technical nature that may require or utilize engineering knowledge and applications. Others will find no employment in engineering related occupations. We use this categorization for the experienced labour force, defined as those who worked in 1995 and/or 1996 and who reported an occupation.

Following the research design employed in our initial study, we limit our analysis to men, who are between ages 30 and 54. Most engineering majors are men and numbers of women become very small when undertaking an analysis of differences by birth place. The age limits are chosen because they exclude variations associated with school completion and selective early retirement. The designated population, men age 30-54, must meet three additional criteria: 1) they have at least 16 years of schooling (a stipulation of the CCPE for accreditation); 2) they have bachelor degrees or higher (also part of the CCPE accreditation requirements); and 3) they declare engineering fields as their areas of major study in the 1996 census.

In examining country of origin variations, the employment patterns of three groups are compared: 1) the Canadian born as a benchmark reference group; 2) immigrants who entered Canada as permanent residents before age 19; and 3) immigrants who entered Canada as permanent residents at age 28 or later and arrived by 1994 . We require this latter group to have legally entered Canada by 1994 for two reasons. First, this restriction means they are at least age 30 by the date of the 1996 census. Second, it minimizes the initial impact of arrival, often associated with no employment and downward mobility (Badets \& Howatson-Leo 1999).

The group omitted from our study are those who immigrated between ages 19 and 27. This group represents 14 percent of the entire designated population, or 30 percent of the designated permanent resident or "immigrant/foreign-born" population (men age 30-54 with at least 16 years of education, at least a bachelors degree and engineering as a major field of study) ${ }^{2}$. The restriction of foreign-born 
Skilled Immigrant Labour: Country of Origin and the Occupational Locations of Male Engineers

men to those immigrating between ages $0-18$ and those immigrating at age 28 or later acts as a proxy for where the last degrees are received. The Canadian census currently does not ask for the geographical location of the last degree, thereby preventing a precise grouping of those who received engineering degrees from Canadian institutions or from institutions in other countries. We assume that most, if not all, of the Canadian born and those permanent residents immigrating before age 19 have received degrees from Canadian institutions. Since education generally is completed by the mid-twenties, we assume that most immigrants arriving at age 28 or later have received their degrees outside Canada. The location where the highest degree was received is far more ambiguous for those immigrating between ages 19-27. As a result, this group is not considered in our paper.

Even with census data, the focus on a specific profession means that numbers are not large, especially when country of birth is of interest. Our criteria for listing a country rather than a region was that population estimates be close to a thousand. Surprisingly, given past and present linkages between American and Canadian economies, the United States was not eligible for a separate designation under this criteria. Because immigrants are more likely to move as adults rather than as children, only Italy ${ }^{3}$ and Hong Kong had numbers sufficient for separate tabulations for those who were age 30-54 in the 1996 census and who immigrated before age 19 (Table 3$)^{4}$.

\section{Engineers at Work}

A first look at the characteristics of men with engineering training reveals considerable variability in their demographic and labor market relevantcharacteristics (Table 3). Compared to the Canadian born or those who arrived as children, immigrants arriving after age 27 are older on average. They obviously have lived fewer years in Canada. Consistent with patterns of recent settlement, they have the highest percentages living in Canada's three major Census Metropolitan Areas (CMAs), comprised of Montreal, Toronto, and Vancouver. They also are less likely to speak only English and/or French at home, particularly if born in Eastern European countries, Iran, the People's Republic of China, Hong Kong, the Philippines and other East Asian countries. Those born in countries other than the United Kingdom, the United States and European countries are likely to be members of Canada's designated visible minority groups, with percentages being the highest for those born in Asian countries.

Given the requirement that the population under study have at least 16 years of education, average years of education is not a sensitive indicator of differences among groups in educational attainments. However, variations exist in the percentages who have gone beyond the bachelors degree by 'generation' (Canadianborn, immigrated before age 19; and immigrated after age 27) and birth place. On average, one in five of the Canadian born and those immigrating as children have a masters or Ph.D., ranging from slightly more than one in ten for those immigrating as children and born in Southeast Asian countries to nearly one in three of those born in Africa (of whom 30 percent are born in Egypt). Men who 


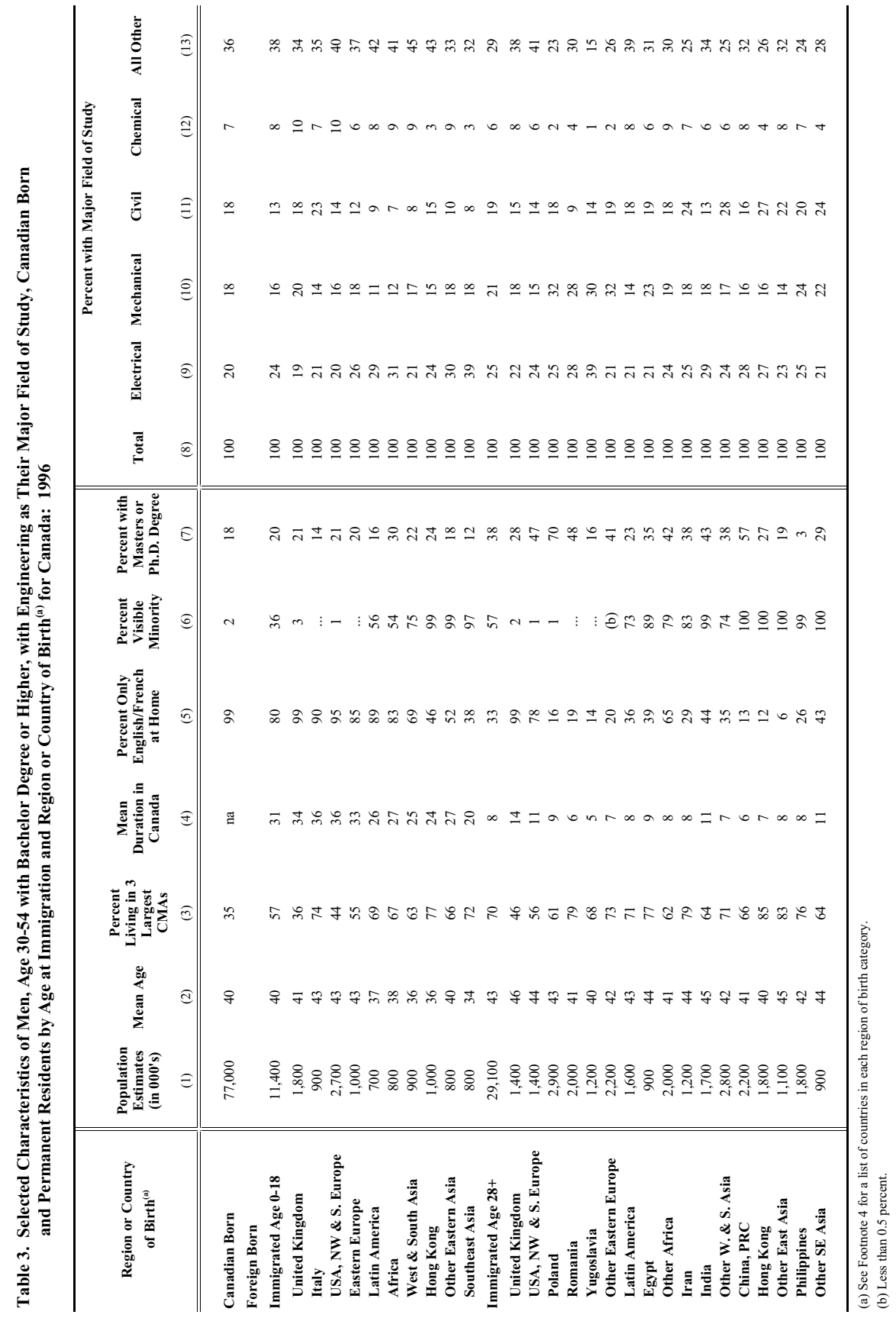




\section{Skilled Immigrant Labour: Country of Origin and the Occupational Locations of Male Engineers}

immigrate at age 28 or later are the most likely of all "generation" groups to have earned degrees beyond the bachelors, but again there are sizable birth place variations, ranging from those born in Poland (70 percent) to those born in the Philippines ( 3 percent).Census data cannot explain why those immigrating as adults have higher percentages with degrees beyond the bachelors, but two possible explanations exist. First and foremost, $\mathrm{Canada}=\mathrm{s}$ immigration selection system favors the selection of the better educated, particularly among those entering on the basis of their economic contributions. As noted earlier, the majority of recent immigrants declaring engineering as their occupations, were admitted on the basis of such contributions (Tables 1 and 2). Second, some men immigrating as adults may have undergone an accreditation process in Canada, and taken an extra degree as part of that process.

Does studying engineering in university and beyond imply employment in engineering occupations? Yes, but only to a point, and the percentages vary by birth place and age at immigration. Of those in the experiencedlabor force, approximately two in five men who are either Canadian-born or immigrated before age 19 hold engineering occupations(Table 4). Over one-quarter hold managerialoccupations and only one in 10 are in occupations that are neither managerial occupations or in engineering or related technical occupations. Of those whose who arrived as children and are born in those born in the United Kingdom, Italy and Africa (which includes Egypt as a major source country), comparatively high percentages hold engineering or manager occupations. Those born in Hong Kong, Other East Asian countries and in Southeast Asia have close to half in engineering occupations but lower percentages in managerial occupations. Men from Latin America and the Caribbean and from Southeast Asia also are more likely than other birthplace groups to hold occupations in technical occupations.

More substantial contrasts exist for men who immigrate as adults, after the age of 27. Between two-thirds and three-fourths of men born in the United Kingdom or in the USA, and select European and Oceanic countries (see footnote 4) are found in either manager or engineeringoccupations (Table 4, panel 3). At the other end of the spectrum are men born in the Philippines where 16 percent hold manager or engineering jobs and where nearly three-quarters are in occupations unrelated to engineering training. Men born in Poland, other Eastern European countries, excluding Romania and Yugoslavia (5), and Iran also are more likely than other groups to have occupations that are not related to engineering training.

Three main conclusions emerge from the univariate occupational distributions. First, as measured by percentages in manager and engineering occupations, the fit between field of study and occupational location is highest for the Canadian born and for men born in the U.K., the USA, Europe (excluding Eastern Europe) and Oceania. Second, as measured by the percentages in occupations unrelated to engineering or technical in nature, the fit between field of study and occupational location is lowest for men immigrating as adults, particularly those born in the Philippines, Iran, Poland and Latin America. 
Table 4

Occupational Group $^{(\text {a) }}$ for Men, Age 30-54 with Bachelor Degree or Higher, with Engineering as Their Major Field of Study, Canadian Born and Permanent Residents by Age at Immigration and Region or Country of Birth for Canada: 1996

\begin{tabular}{|c|c|c|c|c|c|}
\hline \multirow[b]{2}{*}{$\begin{array}{c}\text { Region or } \\
\text { Country of Birth }\end{array}$} & \multirow[b]{2}{*}{$\begin{array}{c}\text { All } \\
\text { Occupations } \\
\text { (1) }\end{array}$} & \multicolumn{4}{|c|}{ Occupational Group $^{(a)}$} \\
\hline & & $\begin{array}{c}\text { Managers } \\
\text { (2) }\end{array}$ & $\begin{array}{c}\text { Engineers } \\
\text { (3) }\end{array}$ & $\begin{array}{c}\text { Technical } \\
\text { (4) }\end{array}$ & $\begin{array}{c}\text { All Other } \\
\text { Occupations } \\
\text { (5) }\end{array}$ \\
\hline Canadian Born & 100 & 28 & 41 & 12 & 19 \\
\hline \multicolumn{6}{|l|}{ Foreign Born $^{(\mathbf{b})}$} \\
\hline Immigrated Age 0 - 18 & 100 & 26 & 40 & 13 & 20 \\
\hline United Kingdom & 100 & 30 & 39 & 13 & 18 \\
\hline Italy & 100 & 32 & 39 & 11 & 19 \\
\hline USA, NW \& S. Europe & 100 & 28 & 39 & 12 & 20 \\
\hline Eastern Europe & 100 & 29 & 35 & 13 & 23 \\
\hline Latin America & 100 & 22 & 38 & 20 & 20 \\
\hline Africa & 100 & 36 & 41 & 7 & 16 \\
\hline West \& South Asia & 100 & 27 & 37 & 10 & 26 \\
\hline Hong Kong & 100 & 17 & 47 & 16 & 20 \\
\hline Other Eastern Asia & 100 & 21 & 43 & 11 & 25 \\
\hline Southeast Asia & 100 & 6 & 51 & 24 & 19 \\
\hline Immigrated Age 28+ & 100 & 18 & 31 & 16 & 35 \\
\hline United Kingdom & 100 & 34 & 40 & 9 & 17 \\
\hline USA, NW \& S. Europe & 100 & 32 & 34 & 15 & 19 \\
\hline Poland & 100 & 13 & 32 & 15 & 41 \\
\hline Romania & 100 & 7 & 40 & 24 & 29 \\
\hline Yugoslavia & 100 & 7 & 44 & 28 & 21 \\
\hline Other Eastern Europe & 100 & 13 & 31 & 16 & 39 \\
\hline Latin America & 100 & 14 & 27 & 18 & 40 \\
\hline Egypt & 100 & 17 & 33 & 20 & 30 \\
\hline Other Africa & 100 & 14 & 36 & 18 & 32 \\
\hline Iran & 100 & 27 & 22 & 11 & 41 \\
\hline India & 100 & 18 & 36 & 14 & 32 \\
\hline Other W. \& S. Asia & 100 & 25 & 27 & 11 & 37 \\
\hline China, PRC & 100 & 14 & 37 & 23 & 27 \\
\hline Hong Kong & 100 & 18 & 30 & 25 & 26 \\
\hline Other East Asia & 100 & 39 & 15 & 9 & 37 \\
\hline Philippines & 100 & 6 & 10 & 12 & 73 \\
\hline Other SE Asia & 100 & 17 & 37 & 11 & 35 \\
\hline
\end{tabular}

(a) For those in the experienced labor force.

(b) See Footnote 4 for a list of countries of birth in each region of birth category. 
Skilled Immigrant Labour: Country of Origin and the

Occupational Locations of Male Engineers

\section{Variations by Birth Place}

Several explanations exist for these patterns. As discussed in the preceding section, one possibility is that birthplace differences in the fit between fields of study and occupational location reflect differences in demographic and human capital profiles, shown in Table 3. Certainly, for men immigrating as adults, pronounced birth place differences exist in length of time spent in Canada (duration), degrees beyond the bachelors, and in whether or not only English and/or French are spoken in the home. These differences could underlie the better occupational fit experienced by men born in the UK, the USA, Europe (excluding Eastern Europe) and Oceania compared to those born in countries such as Poland, Iran, and other areas.

We undertake a multivariate analysis to assess this possibility. If variations by birth place remain after adjusting for the effects of demographic and human capital variables, then other explanations need to be considered. In this analysis, core control variables are age, place of residence, level of degree (bachelors versus higher degrees) and engineering field of study (electrical, mechanical, civil, chemical and all other engineering fields). These variables are discussed and examined in greater detail in Boyd and Thomas (2001). For men immigrating as adults, two additional control variables are language spoken at home and duration in Canada (these variables were not significant for immigrants arriving before age 19). Because our dependent variables are categorical variables, multinomial logistic regression (Liao 1994) is used. The technique relies on the computation of logits reflecting the natural $\log$ of the odds (log odds) of being in engineering occupations relative to managerial, technical or all other occupations [6]. The data are weighted so that statistical tests of significance correspond to those that would be observed for the actual size of the generation groups in the $2 \mathrm{~B}$ census database.

Logits are presented in Tables 5 and 6 for the three-generation groups. The effects of variables such as education, place of residence, and field of study is discussed in Boyd and Thomas (2001). In this paper the focus is on variations by place of birth. Although birth place exerts an overall significant effect in the models for both groups of foreign born men, a comparison of the logits in Tables 5 (columns 4-6) and Table 6 (columns 1-6) shows that most of the logits for birth place groups immigrating as children are not significantly different from the effect of United Kingdom birth. However, logits for those immigrating as adults tend to be significant. Stated somewhat differently, among men immigrating as children, the only significant log odds (and by implication the odds) of holding an engineering occupation rather than a managerial occupation are for those born in Hong Kong or Southeast Asia compared to the log odds for United Kingdom birth place (Table 5). In contrast for those immigrating after age 27 , for the same comparison of occupational outcomes (engineering versus managerial occupations), significant log odds exist for many more birth place groups relative to men born in the United Kingdom (Table 6). 


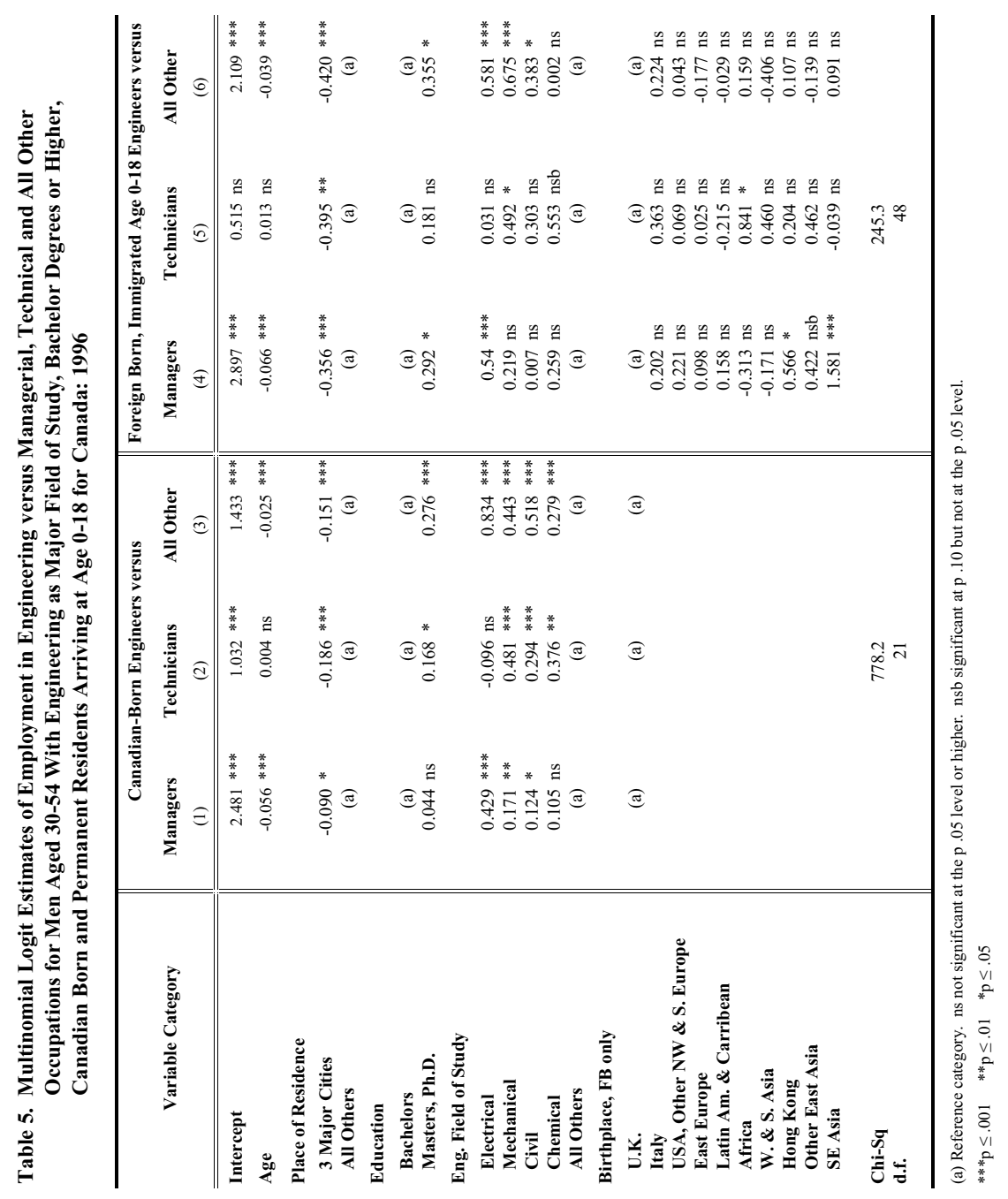




\section{Skilled Immigrant Labour: Country of Origin and the Occupational Locations of Male Engineers}

After controlling for age, residence in Canada's three major cities, education, and engineering field of study, what are the differences among birth place groups in the likelihood of being in engineering occupations versus other types of occupations? We answer this question by calculating probabilities from the logits in Tables 5 and 6[7]. Although this procedure requires specifying values for age, place of residence, level of education, and engineering field of study, it facilitates comparisons across all generation groups. We select civil engineering as a major field of study since expertise in this area is used in construction. It therefore is most likely to involve issues of public safety and health associated with re-accreditation demands. Table 7 displays the calculatedprobabilities (expressed as chancesout of 100) for men who are age 40, who are living in Montreal, Toronto, and Vancouver, and whose highest degree is the bachelor's degree. Foreign-born birthplace groups are ranked in order of the highest probabilities of being in managerial and engineering occupations (Table 7, column 1) with the probabilities of being in one of four occupational clusters also shown (Table 7, columns 4 - 7).

The probability patterns confirm the greater likelihood of being in managerial and engineering occupations for the foreign born immigrating as children (and thus likely to have received degrees inside Canada) compared to those immigrating as adults (and likely to have received degrees outside Canada). It also confirms the advantages associated with birth and, possibly with training, of those born in the United Kingdom, the United States, European (excluding Eastern Europe) and Oceanic countries. For men who immigrated after age 27, those born in Yugoslavia, Hong Kong and in the remainder of East Asia (excluding Hong Kong and the People's Republic of China) occupy the next rung in terms of the chances of being in managerial or engineering occupations. Men who are born in Poland and the Philippines have the lowest probabilities of holding managerial or engineering occupations.

Probabilities for each of the four occupational categories refines, but does not alter, these conclusions (Table 7, columns 4-7). For example, the Canadian born have 30 out of 100 chances of being in managerial occupations and 40 out of 100 chances of holding an engineering occupation. Those born in the U.K. and who immigrated as children have 36 out of 100 chances of being in managerial occupations and 32 chances out of 100 of holding engineering occupations. Those born in Italy and in African countries (including Egypt) and who immigrated as children have even higher chances of employment in managerial occupations. Declines in the probabilities of being in managerial occupations underlies some of the declines in the overall chances of those born in countries and regions as Southeast Asia (excluding the People's Republic of China and Hong Kong), Latin America and the Caribbean, Poland, the Philippines, and Eastern Europe (excluding Poland, Romania and Yugoslavia). These groups have very high chances of holding occupations that are unrelated to engineering.

Less fluency in English and/or French and recency of arrival might also be reasons for the pattern in which men who immigrated as adults and who are born in certain regions or countries have less occupational fit than do those immigrating as children and/or born in the U.K., the U.S., Europe (excluding Eastern Europe) and Oceania. Our analysis found that speaking only English and/or French at home and years 
Table 6

Multinomial Logit Estimates of Employment in Managerial, Engineering, Technical, and All Other Occupations for Men Aged 30-54 With Engineering as Major Field of Study, Bachelor Degrees or Higher, Permanent Residents Arriving at Age 28+ for Canada: 1996

\begin{tabular}{|c|c|c|c|c|c|c|}
\hline Variable Category & \multicolumn{2}{|r|}{$\begin{array}{c}\text { MODEL I } \\
\text { Engineers versus }\end{array}$} & $\begin{array}{l}\text { All Other } \\
\text { (3) }\end{array}$ & \multicolumn{2}{|r|}{$\begin{array}{c}\text { MODEL II } \\
\text { Engineers versus }\end{array}$} & $\begin{array}{l}\text { All Other } \\
\text { (6) }\end{array}$ \\
\hline Intercept & $1.956 * * *$ & $-0.315 \mathrm{~ns}$ & $-0.186 \mathrm{~ns}$ & $2.591 * * *$ & $0.003 \mathrm{~ns}$ & $0.457 \mathrm{~ns}$ \\
\hline Age & $-0.043 * * *$ & $0.036 * * *$ & $0.018 * *$ & $-0.066 * * *$ & $0.019 *$ & $-0.021 * *$ \\
\hline \multicolumn{7}{|l|}{ Place of Residence } \\
\hline $\begin{array}{l}3 \text { Major Cities } \\
\text { All Others }\end{array}$ & $\begin{array}{c}-0.457^{* * *} \\
\text { (a) }\end{array}$ & $\begin{array}{l}-0.170 \mathrm{nsb} \\
\text { (a) }\end{array}$ & $\begin{array}{c}-0.515 * * * \\
\text { (a) }\end{array}$ & $\begin{array}{c}-0.443^{* * *} \\
\text { (a) }\end{array}$ & $\begin{array}{l}-0.154 \mathrm{nsb} \\
\text { (a) }\end{array}$ & $\begin{array}{l}-0.472 * * * \\
\text { (a) }\end{array}$ \\
\hline \multicolumn{7}{|l|}{ Education } \\
\hline $\begin{array}{l}\text { Bachelors } \\
\text { Masters, Ph.D. }\end{array}$ & $\begin{array}{l}\text { (a) } \\
0.692 * * *\end{array}$ & $\begin{array}{l}\text { (a) } \\
0.471 * * *\end{array}$ & $\begin{array}{c}\text { (a) } \\
1.101\end{array} * * *$ & $\begin{array}{c}\text { (a) } \\
0.681\end{array}$ *** & $\begin{array}{c}\text { (a) } \\
0.457 * * *\end{array}$ & $\begin{array}{l}\text { (a) } \\
1.073 * * *\end{array}$ \\
\hline \multicolumn{7}{|l|}{ Eng. Field of Study } \\
\hline $\begin{array}{l}\text { Electrical } \\
\text { Mechanical } \\
\text { Civil } \\
\text { Chemical } \\
\text { All Others }\end{array}$ & $\begin{array}{l}0.539 \text { *** } \\
0.335 \text { ** } \\
0.018 \mathrm{~ns} \\
0.119 \mathrm{~ns} \\
\text { (a) }\end{array}$ & $\begin{array}{c}-0.134 \mathrm{~ns} \\
0.362 * * \\
0.185 \mathrm{~ns} \\
0.498 * \\
\text { (a) }\end{array}$ & $\begin{array}{c}0.431 * * * \\
0.107 \mathrm{~ns} \\
-0.007 \mathrm{~ns} \\
-0.044 \mathrm{~ns} \\
\text { (a) }\end{array}$ & $\begin{array}{l}0.534 * * * \\
0.335 * * \\
0.018 \mathrm{~ns} \\
0.109 \mathrm{~ns} \\
\text { (a) }\end{array}$ & $\begin{array}{c}-0.131 \mathrm{~ns} \\
0.3744^{* *} \\
0.190 \mathrm{~ns} \\
0.489 * \\
\text { (a) }\end{array}$ & $\begin{array}{c}0.440 * * * \\
0.130 \mathrm{~ns} \\
0.008 \mathrm{~ns} \\
-0.073 \mathrm{~ns} \\
\text { (a) }\end{array}$ \\
\hline \multicolumn{7}{|l|}{ Birthplace, FB Only } \\
\hline U.K. & (a) & (a) & (a) & (a) & (a) & (a) \\
\hline USA, Other NW \& S. Europe & $-0.281 \mathrm{~ns}$ & $-0.677 *$ & $-0.394 \mathrm{~ns}$ & $-0.230 \mathrm{~ns}$ & $-0.605 *$ & $-0.217 \mathrm{~ns}$ \\
\hline Poland & $0.345 \mathrm{nsb}$ & $-0.858 * * *$ & $-1.475 * * *$ & 0.388 nsb & $-0.692 *$ & $-1.090 * * *$ \\
\hline Romania & $1.329 * * *$ & $-0.834 * *$ & $-0.493 *$ & $1.444 * * *$ & $-0.628 *$ & $0.008 \mathrm{~ns}$ \\
\hline Yugoslavia & $1.484 * * *$ & $-0.683 *$ & $0.227 \mathrm{~ns}$ & $1.598 * * *$ & $-0.469 \mathrm{nsb}$ & $0.753 * *$ \\
\hline Other East Europe & $0.564 * *$ & $-0.792 * *$ & $-1.023 * * *$ & $0.652 * *$ & $-0.603 *$ & $-0.555 *$ \\
\hline Latin America \& Carribean & $0.477 *$ & $-0.948 * * *$ & $-1.015 * * *$ & $0.543 *$ & $-0.803 * *$ & $-0.66 * *$ \\
\hline Egypt & $0.540 *$ & $-0.957 * *$ & $-0.636 *$ & $0.572 *$ & $-0.843 * *$ & $-0.321 \mathrm{~ns}$ \\
\hline Other Africa & $0.518 *$ & $-0.687 *$ & $-0.724 * * *$ & $0.578 * *$ & $-0.594 *$ & $-0.485 *$ \\
\hline Iran & $-0.459 \mathrm{nsb}$ & $-0.751 *$ & $-1.445 * * *$ & $-0.364 \mathrm{~ns}$ & $-0.571 \mathrm{~ns}$ & $-1.020 * * *$ \\
\hline India & $0.457 *$ & $-0.538 \mathrm{nsb}$ & $-0.772 * * *$ & $0.475 *$ & $-0.439 \mathrm{~ns}$ & $-0.508 *$ \\
\hline Other W. \& S. Asia & $-0.221 \mathrm{~ns}$ & $-0.514 \mathrm{nsb}$ & $-1.105 * * *$ & $-0.152 \mathrm{~ns}$ & $-0.366 \mathrm{~ns}$ & $-0.731 * * *$ \\
\hline China & $0.533 *$ & $-0.958 * * *$ & $-0.664 * *$ & $0.610 * *$ & $-0.762 * *$ & $-0.190 \mathrm{~ns}$ \\
\hline Hong Kong & $0.283 \mathrm{~ns}$ & $-1.061 * * *$ & $-0.406 \mathrm{nsb}$ & $0.301 \mathrm{~ns}$ & $-0.912 * *$ & $-0.047 \mathrm{~ns}$ \\
\hline Other East Asia & $-0.950 * * *$ & $-0.873 *$ & $-1.466 * * *$ & $-0.890 * * *$ & $-0.679 \mathrm{nsb}$ & $-0.981 * * *$ \\
\hline Philippines & $0.520 \mathrm{nsb}$ & $-1.363 * * *$ & $-2.393 * * *$ & $0.545 \mathrm{nsb}$ & $-1.267 * * *$ & $-2.112 * * *$ \\
\hline Other SE Asia & $0.609 *$ & $-0.220 \mathrm{~ns}$ & $-0.689 * *$ & $0.606 *$ & $-0.133 \mathrm{~ns}$ & $-0.469 \mathrm{nsb}$ \\
\hline $\begin{array}{l}\text { Home Language } \\
\text { English/French only } \\
\text { Other Languages }\end{array}$ & & & & $\begin{array}{c}-0.083 \mathrm{~ns} \\
\text { (a) }\end{array}$ & $\begin{array}{l}0.107 \mathrm{~ns} \\
\text { (a) }\end{array}$ & $\begin{array}{l}0.241 * * \\
\text { (a) }\end{array}$ \\
\hline Years in Canada & & & & $0.037^{* * *}$ & $0.027 * *$ & $0.067 * * *$ \\
\hline $\begin{array}{l}\text { Chi-Sq } \\
\text { d.f. }\end{array}$ & & $\begin{array}{r}1235.4 \\
69\end{array}$ & & & $\begin{array}{r}1328.1 \\
75\end{array}$ & \\
\hline
\end{tabular}




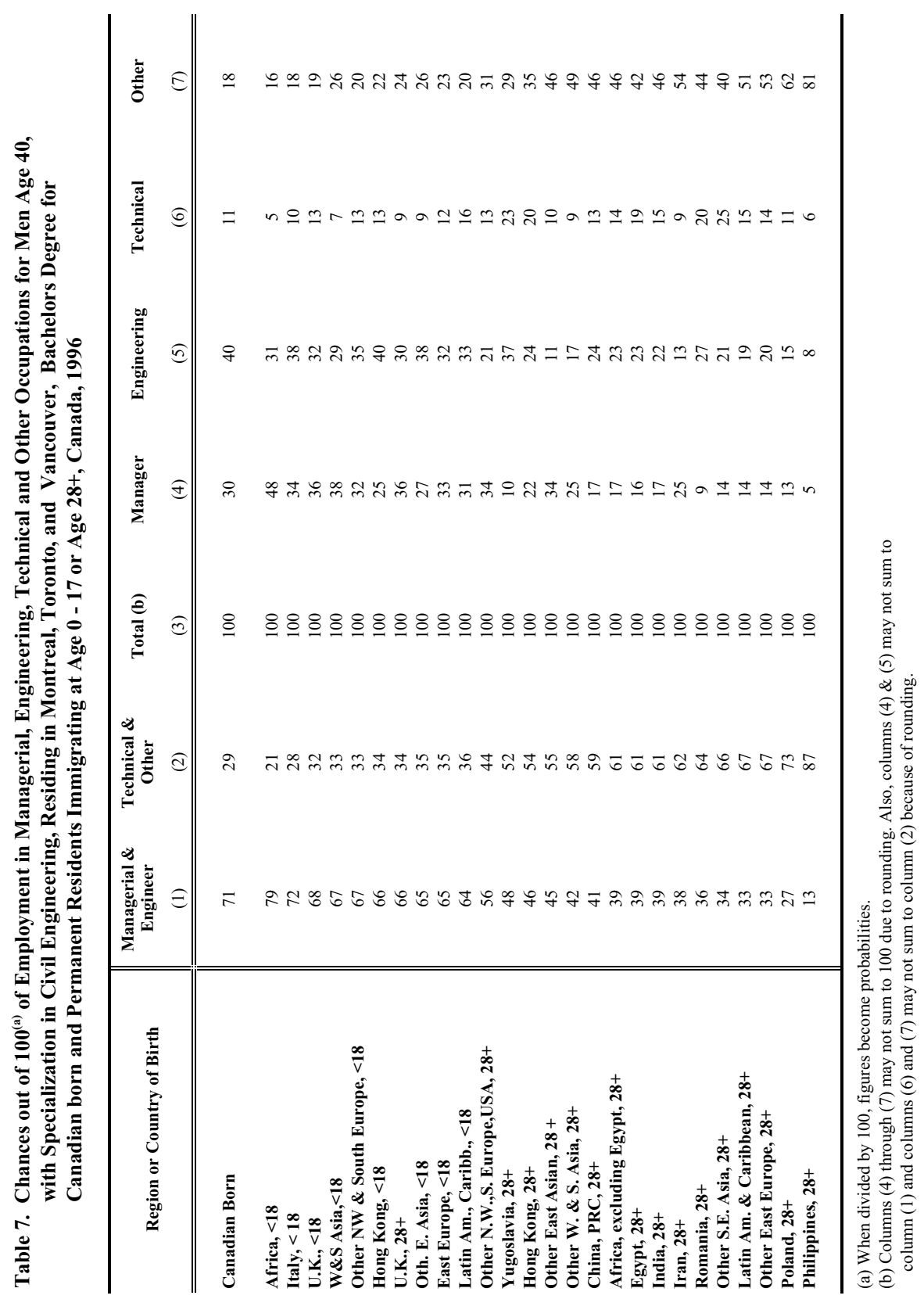


spent in Canada are not significant determinants of occupational location for the foreign born immigrating as children. They are important determinants of occupational location for men immigrating as adults. Probabilities of being in a managerial or engineering occupation are higher for those who speak only English and/or French in the home, compared to those who speak other languages either solely at home or in combination with English and/or French. And the probabilities also increase with time spent in Canada (Table 8).

However, when language at home and duration are included as additional control variables (Table 6, columns 4-6) for those immigrating after age 27 , the overall pattern does not appreciably change. This is evident in two ways. First, the magnitude of the birthplace specific logits declines only slightly. Second, the birthplace hierarchy produced by calculating probabilities for men immigrating after age 27 persists with only a few minor inflections (Table 8). Regardless of whether only English and/or French is spoken in the home and duration in Canada, the chances of being in managerial or engineering occupations are highest for men born in the U.K., or in the USA, Europe (excluding Eastern Europe) or in Oceania and lowest for those born in Latin America and the Caribbean, Poland, Eastern Europe (excluding Poland, Romania and Yugoslavia) and the Philippines.

\section{Conclusions}

Several general conclusions emerge from our multivariate analysis. Men who are the most likely to have received training from Canadian institutions (the Canadian born and the foreign born immigrating before age 19) are also the most likely to be employed in engineering and/or managerial occupations. Conversely, with the exception of those born in the United Kingdom and to a lesser extent the U.S., European (excluding Eastern Europe) and Oceanic countries, those most likely to have been trained outside Canada (those immigrating after age 27) are less likely to be employed in managerial and/or engineering occupations. Second, for those immigrating after age 27, probabilities of holding managerial or engineering occupations are very low for those born in the Philippines, Poland, other areas of Eastern Europe (excluding Yugoslavia and Romania) and who have studied civil engineering, are age 40 , hold bachelors degrees, and live in one of Canada $=\mathrm{s}$ three largest cities.

What explains such patterns? A extensive literature documents Canada $=$ s ethnic and racial stratification in the labour market, and our findings parallel others in which those of British, American and European descent experience substantial advantages compared to those carrying racialized markers (see: Henry et. al., 2000; Satzewich, 1998). However, despite indications of polarization by origins, our more nuanced findings suggest factors other than direct discrimination and racialization are operative. To be sure, men who born in the U.K., the U.S.A., Europe (excluding Eastern Europe) and Oceania are more likely to be employed in managerial and engineering occupations. Among those immigrating as adults, the Philippine born are the least likely to be in such occupationsand the most likely to hold occupations unrelated to engineering training. However, for men immigrating as children, birth- 


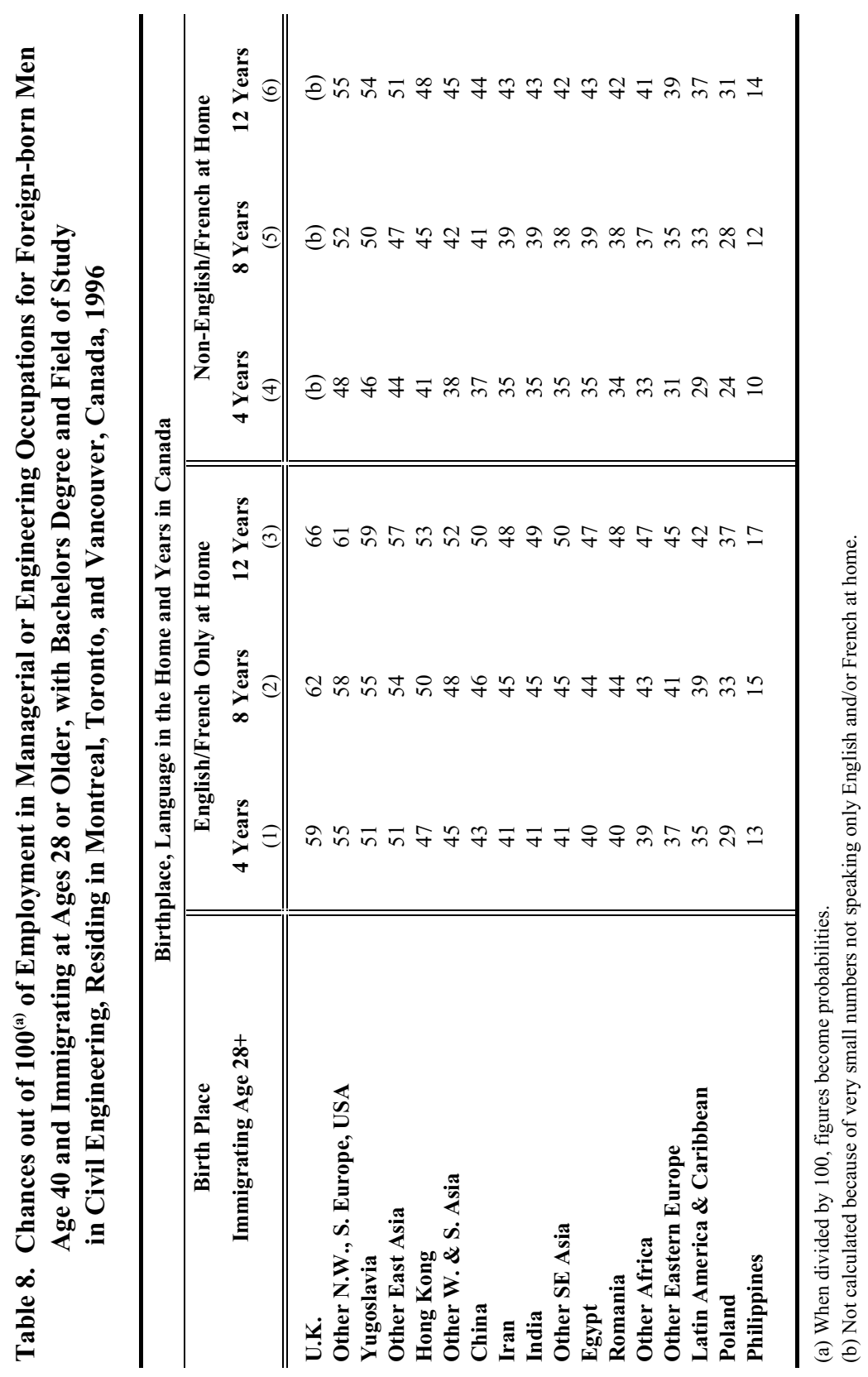


place differences vis-a-vis the U.K. born are rarely significant in our multivariate models. The range of calculated probabilities also is narrow, particularly when comparing men born in the United Kingdom through to those born in Latin American and Caribbean countries (Table 7). For men immigrating as adults, those born in Hong Kong are quite likely to hold engineering occupations (log odds for being in engineering compared to managerial occupations are not significantly different from those born in the U.K.) and those born in Poland and Eastern European countries (excluding Yugoslavia and Romania) are not. In sum, there is not a monolithic bifurcation of groups based on first, second and third world distinctions nor one always corresponding with colour.

Additional explanations are entry status, educational content, and accreditation requirements. That context of entry matters for migrant integration is well understood, both theoretically (Portes and Borocz, 1989) and in practice. Refugees in particular may be handicapped in the labour market, not just in the recency of their arrival or their language knowledge, but also by limitations on abilities to plan for migration and perhaps by traumas associated with the conditions producing migration and with the flight process itself (Beiser, 1999; Waxman, 2001). Starting with the break-up of the former USSR in 1989, conditions in many Eastern deteriorated during the early 1990s and produced refugee like flows during that period. These flows may partially explain our findings that men who immigrated as adults and who are from Eastern European countries, particularly those well entrenched in the U.S.S.R orbit, are less likely than others to be employed in managerial or engineering occupations. Refugee related impacts also may affect some men born in select Latin American countries and those born in Iran.

Counterfactual to this reasoning is the finding that men born in Yugoslavia are quite likely to be working in engineering occupations. However, this 'counterfactual' highlights the multiplicity and complexity of the factors that influence the fit between education and occupational location. No one single explanation is likely to explain the labour market locations of any particular birth place group or that of all men born in a particular country. The level and content of education may be additional factors that help explain the differences between men born in Yugoslavia and elsewhere in Eastern Europe. The Masters of Science in Engineering obtained in many Eastern European countries is not considered equivalent to the same degree in Canada. Much of the educational training can be done by correspondence and the content is closer to that acquired by a technician or technologist (personal conversation, CCPE staff, Ottawa, June 6, 2001). Census data cannot tell us the content of the higher degrees received by the men in our study. However, of those who immigrated as adult, seven out of ten men born in Poland have degrees that are higher than bachelor's degrees as do nearly half of those born in Romania and 41 percent of those born in other areas of Eastern Europe. Only 16 percent of men born in Yugoslavia have degrees beyond the bachelors.

Variations in educational content refocuses attention on accreditation as a possible explanation for birth place differences in the occupational location of men with engineering training. The small birthplace differences for men who immigrated as children are consistent with the argument that men who receive their training from Canadian institutions on the whole do not experience accreditationdifficulties to the 


\section{Skilled Immigrant Labour: Country of Origin and the Occupational Locations of Male Engineers}

same extent as those who have received their training elsewhere. The findings for men who immigrated as adults and who are born in the U.K. and in the U.S.A., Europe (excluding Eastern Europe), Oceania and in Hong Kong also are what we expected given mutual international agreements between CCPE and other bodies. So too are the findings for men born, and presumably trained, in the Philippines. The intertwined effects of educational content and accreditation requirements are likely to be present for other birth place groups although better understanding of the effects is hampered by the absence of information on programs of study in the schools from which degrees were obtained.

In conjunction with recent revisions in immigration policy, our empirical findings suggest that the accreditation of skilled immigrant labour is likely to remain a major issue in the near future. Canada's participation in a global economy has gone hand in hand with growing attention to the recruitment of skilled foreign-born labour through federal policy initiatives. In addition to NAFTA and the associated movement of temporary labour across the Canadian-United States border, recent immigration policy changes also emphasize skilled permanent immigration. Following a review process begun in 1996 (Citizenship and Immigration, 2001c), a new Immigration and Refugee Protection Act (Bill C-31) was tabled on April 6, 2000 in Parliament. As a result of the federal election (Fall, 2000), the legislative process needed to pass the bill was not completed. A new bill to replace Bill-31, Bill-11, was tabled on February 21, 2001 and was proclaimed November 1, 2001.

Intended to replace the Immigration Act, 1976 and subsequent legislation, the new Immigration and Refugee Protection Act (IRPA) and its accompanying regulations will contain a number of provisions designed to expand the admission of workers with the skills that are most needed in Canada (Citizenship and Immigration, 2001a). Between February and November, 2001, CIC signaled the following changes to previous admissibility requirements. The General Occupations list will no longer be used in determining the admissibility of skilled workers (Citizenship and Immigration, 1999; also see: www.cic.gc.ca/english/immigr/occ/).Instead more weight will be assigned to education and knowledge of an official language. An "in-Canada landing class" also will be created for temporary workers (including recent graduates from Canadian schools) who have a permanent job offer and who have been working in Canada. In addition, the Temporary Worker Program will be expanded (Citizenship and Immigration, 2001b).

Left unaddressed in the various media releases were potential difficulties associated with admitting more skilled workers in professions and trades requiring accreditation or licenses. In their March 22, 2001 evidence to the Standing Committee on Citizenship and Immigration (Canada, Parliament of. 2001: 0915 - 0930), representatives of the Coalition of Regulatory Related Agencies and the Canadian Council of Professional Engineers expressed concerns and made specific recommendations for change to the then-pending Bill-11. Included in their recommendations were two that would have increased the involvement of licensing associations and regulatory bodies. One recommendation sought to gain recognition for the role played by Canada's regulatory agencies in licensing and accreditation. A second sought to alter the selection model for skilled workers by requiring 
evidence that the applicant has met or had a reasonable expectation of meeting the requirements of the appropriate regulatory body in Canada.

On December 15, 2001, the first set of proposed regulations was published in the Canada Gazette (Canada, 2001:4477 - 4698). As expected, a new selection grid exists which emphasizes human capital skills rather than intended occupation. For persons entering in the Skilled Worker Category, the definition of a skilled worker is altered to refer to someone who has at least one year of work experience within the past ten years in one of the occupationslisted as Skill Level O (Managers), Skill Level A (primarily professionals) and Skill Level B (technical, skilled trades, and paraprofessional occupations). Overall, the stance appears to be that of broadening the skilled worker pool rather than restricting the pool by invoking requirements of professional licensing bodies. The proposed regulations waive the previous requirement of meeting the Employment Requirements of the NOC, some of which indicate that a particularoccupation require completion of a certain type of university degree or membership in a designated Canadian professional association. Eliminating this requirement is rationalized on the grounds that a) many skilled immigrants experience considerable difficulty in meeting some Canadian requirements before their arrival in Canada; and b) some Canadians employers may not require experienced job applicants to meet the same entry requirements as new entrants to the job market (Canada. 2001: 4510-4512). In addition, the analysis statement which precedes the regulations explicitly mentions the rejection of "... the Australian approach requiring pre-approval of each applicantby a regulated credential and licensing evaluation body" (Canada, 2001: 4518).

These regulatorychanges are intended to attract skilled workers to Canada. However, immigration law and regulations have no jurisdiction over domestic labour regulations. As a result, accreditation and licensing requirements of select Canadian professions and trades will continue to apply to workers once they reside in Canada. Two consequences may be anticipated. First, for immigrants trained in professions such as engineering,country of origin differenceswill persist in the fit between field of study and occupations. In turn, this aspect of stratification among the higher skilled will fuel ongoing concerns and discussions surrounding accreditation of foreign trained labour in Canada.

\section{Acknowledgements:}

The authors alone are responsible for the analysis, text and interpretations presented in this paper. The views expressed in this paper are those of the authors and do not necessarily reflect those held by any association or organization. 
Skilled Immigrant Labour: Country of Origin and the Occupational Locations of Male Engineers

\section{End Notes:}

1. A description of the occupations in each category is briefly described in Boyd and Thomas, 2001, Appendix A. In that paper, university professors in engineering were classified as managerial occupations. In this study of variations by country of origin, university professors in engineering are place in the engineering occupational category.

2. Of the entire male population of permanent residents who are age 30-54 in 1996, immigrated by 1994, have at least 16 years of education, at least a bachelor's degree and whose major field of study was engineering, 18 percent immigrated between the ages of $0-18 ; 30$ percent between ages $19-27$; and 52 percent at age 28 or later.

3. Post-war Italian migration occurred primarily in the 1950s and 1960s and it did not consist of many skilled workers. Clearly, some males who arrived as children studied engineering in university. However, many who arrived as adults did not, and along with declining immigration from Italy in the 1980s and $1990 \mathrm{~s}$, the numbers were not large enough to list Italy as a separate country for those arriving after age 27 (Table 3).

4. The following countries are represented in the regional groupings for permanent resident, foreign-born men, age 30-54 in 1996 who have 16 or more years of schooling, have bachelor degrees or higher, and whose major field of study was engineering: USA, UK, Europe, Other: United States, Austria, Belgium, France, Germany, Netherlands, Switzerland, Ireland, Republic Of, United Kingdom, Denmark, Finland, Norway, Sweden Andorra, Greece, Italy, Malta, Portugal, Spain, Australia, Fiji, New Zealand. East Europe: Bulgaria, Czech Republic, Slovakia; Czechoslovakia, n.i.e., Hungary, Poland, Romania, Estonia, Latvia, Lithuania, Belarus, Moldova, Republic Of, Russian Federation, Ukraine, U.S.S.R., n.i.e., Albania, Bosnia and Herzegovina, Croatia, Macedonia (Fyrom), Slovenia, Yugoslavia. Latin America \& Carribean: Costa Rica, El Salvador, Guatemala, Honduras, Mexico, Nicaragua, Panama, Barbados, Cuba, Dominican Republic, Grenada, Haiti, Jamaica, Martinique, Netherlands Antilles, Puerto Rico, Saint Kitts and Nevi, Trinidad and Tobago, Argentina, Bolivia, Brazil, Chile, Colombia, Ecuador, Guyana, Paraguay, Peru, Suriname, Uruguay, Venezuela. Africa: Benin, Burkina Faso, Cote D'Ivoire, Ghana, Guinea, Liberia, Mali, Mauritania, Niger, Nigeria, Senegal, Sierra Leone, Togo, Burundi, Eritrea, Ethiopia, Kenya, Madagascar, Malawi, Mauritius, Mozambique, Rwanda, Somalia, Tanzania, United Rep., Uganda, Zambia, Zimbabwe, Algeria, Egypt, Libya, Morocco, Sudan, Tunisia, Cameroon, Central African Republic, Congo, Zaire, Namibia, South Africa, Swaziland. West Asia: Afghanistan, Cyprus, Iran, Turkey, Armenia, Azerbaijan, Georgia, Kazakstan, Kyrgyzstan, Bahrain, Iraq, Israel, Jordan, Kuwait, Lebanon, Oman, Saudi Arabia, Syria, Yemen, Palestine/West Bank. South Asia: Bangladesh, India, Nepal, Pakistan, Sri Lanka. East Asia: China, Hong Kong, Japan, Korea, South, Macau, Mongolia, Taiwan. 
5. Many classifications of countries into world regions include Yugoslavia under "Southern Europe." However, in our analysis Yugoslavia is included as part of Eastern Europe. This categorization reflects the political and military upheaval associated with the breakup of the U.S.S.R. after 1989, emergence of new geopolitical areas in the "former Yugoslavia," and the refugee-like motivations for migrating that characterized the larger Eastern European region, including those living in former Yugoslavia.

6. The technique relies on the computation of logits reflecting the natural log of the odds (log odds) of being in each occupational category as opposed to some reference category. Tables 5 and 6 express the log odds of being in engineering occupations compared to three reference categories: manager occupations, technical occupations and all others. Most statistical packages calculate logits using the same reference group rather than changing referencegroups as we have done. However, multinomial logistic regressions which are run for these latter three groups compared to one reference group (engineering occupations) will produce the same coefficients but with opposite signs.

7. Another way of assessing the existence and pattern of remaining differences is to exponentiate the logits. This produces the odds of holding engineering occupations relative to the other three occupationalgroups for birthplace groups compared to the reference group (those born in the U.K. for the foreign born generation groups).

\section{References:}

Alarcon, Rafael. 1999. "Recruitment processes among foreign-born engineers and scientists in silicon valley," American Behavioral Scientists 42: 13811397.

Alarcon, Rafael. 2001. "Immigrant niches in the U.S. high-technology industry," in Wayne A. Cornelius and Thomas J. Espenshade, (eds), The International Migration of the Highly Skilled: Demand, Supply, and Development Consequences. La Jolla, Calif.: Center for Comparative Immigration Studies, University of California-San Diego, pp. 235-264.

Atkinson, A.G., K. J. Barnes and Ellen Richardson. 1970. Canada's Highly Qualified Manpower Resources. Ottawa: Department of Manpower and Immigration, Canada: Research Branch, Program Development Service.

Badets, Jane and Linda Howatson. 1999. "Recent immigrants in the work force," Canadian Social Trends. 52 (Spring): 16-22.

Basran, G. S. \& Zong, L. 1998. "Devaluation of foreign credentials as perceived by visible minority immigrants in Canada," Canadian Ethnic Studies 30: 6-23. 
Skilled Immigrant Labour: Country of Origin and the Occupational Locations of Male Engineers

Beiser, Morton. 1999. "Strangers at the Gate: The 'Boat People's' First Ten years in Canada." Toronto: University of Toronto Press.

Bolaria, B. S. 1992. "From immigrant settlers to migrant transients: foreign professionals in Canada," in Victor Satzewich (ed), Deconstructing A Nation: Immigration, Multiculturalism and Racism in 90's Canada. Halifax: Fernwood Press, pp. 212-227.

Boyd, Monica. 1994. "A Matter of Degree: Immigrants, Educational Credentials and Economic Correlates," Paper presented at the Canadian Employment Research Forum (CERF) Workshop on Immigration, Hull, Quebec. March.

Boyd, Monica. 2001. "Asian engineers in Canada," in Wayne A. Cornelius and Thomas J. Espenshade (eds), The International Migration of the Highly Skilled: Demand, Supply, and Development Consequences. La Jolla, Calif.: Center for Comparative Immigration Studies, University of California-San Diego, pp. 85-109.

Boyd, Monica and Derrick Thomas. 2001. "Match or Mismatch? The labor market performances of foreign-born engineers," Population Research \& Policy Review (Special Issue on High-Skill Migration) 20: 107-133.

Boyd, Monica and Michael Vickers. 2000. "100 years of immigration," Canadian Social Trends. 58 (Autumn): 2-12.

Calliste, Agnes. 2000. "Resisting professional exclusion and marginality in nursing: women of colour in Ontario," in Madeline A. Kalbach and Warren E. Kalbach (eds) Perspectives on Ethnicity in Canada: A Reader. Toronto: Harcourt Canada, pp. 303-328.

Canada. Department of Labour, Economics and Research Branch. 1961 (October). The Migration of Professional Workers Into and Out of Canada, 19461960. Bulletin No.11. Ottawa.

Canada. 2001. Canada Gazette/Gazette du Canada, Vol. 135: No. 50: 44774698.

Canada, House of Commons Standing Committee on Citizenship and Immigration. 2001. Evidence. March 22. See:

www.parl.gc.ca/InfoComDoc/37/1/CIMM/Meetings/Evidence/cimmev06e.htm.

Citizenship and Immigration Canada. 1999. Applying as an Independent Immigrant. May. Ottawa. Also see:

http://www.cic.gc.ca/english/immigr/guide-ce.html. 
Citizenship and Immigration Canada. 2001a. Immigration and Refugee Protection Act Introduced. News Release 2001-03. Ottawa. See: www.cic.gc.ca/english/about/policy.

Citizenship and Immigration Canada. 2001b. Making the System Work Better. Backgrounder \# 2. News Release 2001-03. Ottawa. See: www.cic.gc.ca/english/about/policy.

Citizenship and Immigration Canada. 2001c. Milestones On the Road to New Legislation. Backgrounder \# 3. News Release 2001-03. Ottawa. See: www.cic.gc.ca/english/about/policy.

Das Gupta, Tania. 1996. Racism and Paid Work. Toronto: Garamond Press.

Fernandez, Marilyn. 1998. "Asian Indian Americans in the Bay Area and the glass ceiling," Sociological Perspectives 41: 119-149.

Henry, Frances, Carol Tator, Winston Mattis, and Tim Rees. 2000. The Colour of Democracy: Racism in Canadian Society. 2cd edition. Toronto: Harcourt, Brace \& Company, Canada.

Industry Canada. 2001 (March) Consulting Engineering. Service Industries Overview Series.Website: http://strategis.ic.gc.ca/pics/ce/consult-en.pdf

Liao, T. F. (1994). Interpreting Probability Models: Logit, Probit and Other Generalized Linear Models. Thousand Oaks, California: Sage Publications.

Lim, Nelson, Roger Waldinger and Mehdi Bozorgmehr. 1998. "The subjective side of the glass ceiling: immigrant and native differences in job satisfaction," Paper presented at the annual meeting of the American Sociological Association. San Francisco, CA, August.

Mata, Fernando G. 1992. "The Recognition of foreign degrees in Canada: context, development and issue relevance." Paper presented at the Conference on Migration, Human Rights and Economic Integration. Toronto: York University. Centre for Refugee Studies.

Mata, Fernando. 1994. "The Non-accreditation of immigrant professionals in Canada," Paper presented at the annual meeting of the Canadian Sociology and Anthropology Association, Calgary, Alberta..

Mata, Fernando. 1999. "The Non-accreditation of immigrant professionals in Canada: societal dimensions of the problem." Paper presented at the Conference on Shaping the Future: Qualifications Recognition in the 21 st Century, Toronto, Ontario. 
Skilled Immigrant Labour: Country of Origin and the Occupational Locations of Male Engineers

McDade, Kathryn. 1988. Barriers to the Recognition of the Credentials of Immigrants in Canada. Ottawa: Institute for Research on Public Policy.

Parai, Louis. 1965 (June). Immigration and Emigration of Professional and Skilled Manpower During the Post War Period. Special Study No. 1. Ottawa: Economic Council of Canada.

Portes, Alejandro and Josef Borocz. 1989. Contemporary Immigration: Theoretical Perspectives on Its Determinants and Modes of Incorporation. International Migration Review 23 (Fall): 606-630.

Satzewich, Vic (ed.). 1998. Racism \& Social Inequality in Canada. Toronto: Thompson Educational Publishing Company.

Tang, Joyce. 1993a. "Caucasians and Asians in engineering: a study in occupational mobility and departure," in Samuel B. Bacharach (ed.) Research in the Sociology of Organizations. Greenwich, CT: JAI Press, Inc., pp. 217-256.

Tang, Joyce. 1993b. "The Career attainment of Caucasian and Asian Engineers," The Sociological Quarterly 34: 467-496.

Tang, Joyce. 1995. "Differences in the process of self-employment among Whites, Blacks, and Asians: the case of scientists and engineers," Sociological Perspectives 38: 273-309.

Tang, Joyce. 1997. "The Glass ceiling in science and engineering," Journal of Socio-Economics 26: 383-406.

Waxman, Peter. 2001. "The Economic adjustment of recently arrived Bosnian, Afghan and Iraqi refugees in Sydney, Australia," International Migration Review 35 (Summer): 472-505.

Received August 2001; Revised January 2001 